\title{
Symposium Discussion Report: Insolvency of Corporate Groups
}

\author{
September 27, 2013 \\ Milan, Italy \\ by \\ JOANNA WARCHOL ${ }^{1}$
}

The discussion on Insolvency of Corporate Groups focused on the 'Endless problem of Enterprise Groups' insolvency' as presented by A. van Hoe, (Universitet Antwerpen, Faculteit Rechten in Belgium) and 'The COMI - Concept in the Revision of the European Insolvency Regulation (EIR)' presented by Professor D. Latella, (Univesita degli Studi di Messina in Italy) in a panel chaired by Professor M. Kroeze (Erasmus University Rotterdam in the Netherlands). Also addressed were issues such as 'The Role of Shareholders in the Insolvency of a Company' presented by Professor L. Stanghellini, (University of Firenze in Italy) along with an examination of 'Cooperation between Liquidators and Courts in Insolvency Proceedings of Related companies under the Proposed Revised EIR' presented by Assistant Professor M. Reumers, (Open Universiteit in the Netherlands) in a panel chaired by Professor H. Fleischer (Max Planck Institute for Comparative and International Private Law in Hamburg, Germany). Although Associate Professor I. Mevorach from School of Law, University of Nottingham in England was absent from the conference, her article was published in the ECFR in 2013 'Forum Shopping in Times of Crisis: A Directors' Duties Perspective'.

The follow-up discussion demonstrated the timeliness of the topic and the conference. The conference addressed the latest case law in regard to European cross-border insolvency of Corporate Groups in the context of the proposed revision of the European Insolvency Regulation (quoted as EIR) as well as the draft of the EU Directive (from June 2013) and Regulation (from July 2013) aimed at establishing the Single Resolution Mechanism for the European Banking Union. The exchange of views unveiled the paradigm of a legal person in the context of the insolvency law of groups while verifying the theory of 'Eine Person - ein Vermögen - eine Insolvenz' in the modern development of corporate law. Following questions related to the content of the forthcoming EIR provided a useful aid to discussion: - what should prevail, the group's interest or the interest of creditors in insolvency of holdings?; - are the pro-

1 Dr. iur. (Heidelberg University); legal and policy adviser in the European Parliament. 
posed measures an adequate basis to achieve better development in the EU's insolvency and sufficient to reduce bankruptcy tourism?; - what are the criteria to distinguish between 'freedom of establishment', 'forum shopping' and 'momentum of insolvency'?

Benefiting from ten years of experience from the existing regulation on insolvency proceedings (in operation since 31 May 2002), conference participants welcomed the modernization of cross-border insolvency rules and supported the so-called 'second chance' for honest entrepreneurs with the opportunity of restructuration for viable businesses in difficulties rather than liquidation. Whether the new policy could make the supra-national insolvency of groups of related companies more efficient as well as also benefiting both debtors and creditors was considered. The new European framework on insolvency proceedings establishes common rules on the court competent to open insolvency proceedings, the applicable law and the recognition of the court's decisions when a debtor becomes insolvent. The regulation applies whenever the debtors have assets or creditors in more than one Member State.

Due to the lack of specific provisions for group insolvency in the old regulation, participants noted that the prospect of a successful restructuring of the group as a whole has diminished. The new proposal creates a legal framework to deal with the insolvency of several members of a group of companies while maintaining the entity-by-entity approach.

First of all it introduces an obligation to better coordinate insolvency proceedings relating to different members of the same group of companies by obliging the liquidators and the courts involved to cooperate and communicate with each other (i.e. between involved liquidators, courts and between courts and liquidators). Liquidators should notably exchange relevant information while elaborating a rescue plan where this is appropriate. The possibility of enhanced cooperation by way of protocols was explicitly highlighted by participants in order to acknowledge the practical importance of these instruments and promote their use.

Addressed secondly was the mutual standing of liquidators in proceedings for other group members introduced by provisions such as the right to be heard in other proceedings, the right to attend meetings of creditors in other proceedings and the right to propose reorganization plans for other members. Therefore, these tools should actually facilitate reorganization while enabling the liquidator who has the biggest interest in the successful restructuring of all the companies concerned to officially submit his reorganization plan in the proceedings concerning a group member.

The main objective of the regulation is to prevent the transfer of assets belonging to an insolvent debtor or judicial proceedings from one EU country to 
another, while seeking to obtain a more favorable legal position (so called forum shopping or bankruptcy tourism). Looking at the court jurisdiction as determined by the EIR discussed were the provision on main and secondary proceedings ${ }^{2}$ and their impact on national law and practice. In order to find out how to balance the fundamental freedom of the establishment with the distortions caused by 'insolvency tourism', the definition, concept and the criteria applying to the determination of the debtor's Centre of Main Interest (COMI) were analyzed and also considered that COMI of subsidiaries should be located at the holding/parent company.

Discussion confirmed the value of the registration office as the most reliable indicator and the main formal indicators of the firm's seat. Such a publicly accessible insolvency register could increase transparency. Whereas the presumption of jurisdiction could be strengthened by introducing a 'suspect period' in order to combat potential abuses of 'bankruptcy tourism'. Although wording of 'suspected period' needs further clarification in order to become a more accurate alternative solution for the practice.

Seeking a more uniform European insolvency approach, the importance of ensuring consistency of the EU's proposal was emphasized by examples of case law that have developed under the ECJ jurisdiction and recent 'friendly' modernisation of national insolvency laws as in Germany, Ireland, United Kingdom, France, Italy, Cyprus etc. Observing recent 'trends' in national regulation it can be said that bankruptcy is extending its reach from company's assets to the corporate entity itself, while the position of shareholders is changing from a 'property rule' to a 'liability rule'. Shareholders become more like claimants and are no longer as an owners (hence they don't have the right to keep the shares but merely to be compensated for their loss).

In Germany the introduction of a new provision to the Insolvency Code facilitated the forced debt-to-equity swap even against the will of the shareholder's meeting and represented a new attitude in the official interpretation of the earlier ECJ judgments on the 2nd company law directive, as put forward in such cases as 'Pafitis'. Therefore a German Professor clarified that actually the German legislator had carefully considered the restraints arising out of those ECJ rulings and concluded that they would not actually prevent debt-equity swaps as a result of a restructuring out of insolvency. The real implications of the restraints formulated by the ECJ do not lay in actual insolvency (i.e., when the company is either balance-sheet insolvent or illiquid) but in pre-insolvency

2 The main proceeding has to be opened in the Member State in which the debtor has its centre of main interest with proceeding effects recognized in the EU. While the secondary proceeding can be opened where the debtor has an establishment in a Member State, the effects of these proceedings are limited to the assets located in that state. 
restructurings where this threshold has not yet been reached and where, therefore, the residual value of the shareholders' equity position is not (yet) zero.

Dynamic changes in the investment landscape cause problems that have an impact on the group's insolvency. Uniformity of cross-border insolvency proceedings by means of mutual recognition could improve the legal position of groups of companies. However critical views have been expressed about the EC's proposal but the open minded debate of practitioners and academics offered valuable insights from the national perspective contributing to better development of the EU's insolvency law in the Internal Market. 